\title{
Evaluation of Growth Performance of Rats Fed With Sweet Detar, Detarium Microcarpum Fruit as Supplementary Feed Ingredient
}

\author{
*Bamisaye, F.A ${ }^{1}$., Ajani, E.O ${ }^{1}$., Nurain, I.O ${ }^{1}$., Adebisi, K.E ${ }^{1}$., Quadri, R.T ${ }^{1}$. \\ andMinari, J.B ${ }^{2}$. \\ 1. Department of Biosciences and Biotechnology, College of Pure and Applied Sciences, Kwara State \\ University, Malete, P.M.B. 1530, Ilorin, Nigeria. \\ 2. Department of Cell Biology and Genetics, University of Lagos, Lagos State, Nigeria.
}

\begin{abstract}
This research was carried out to evaluate the phytochemicals constituents and nutritional values of mesocarp and seed of sweet detar(Detarium Microcarpum) fruit as supplementary feed ingredient in the diets of rats. Thirty five healthy mixed sexalbino rats of four weeks old were divided into five groups of seven rats each and fed with different ratios(M1:2R;M2:1R; S1:2R and S2:1R) of mesocarp and seed of D. microcarpum. Data were collected on feed intake and growth rate was observed.

At the end of the experiments, saponins, phenolics and terpenoids were detected in both the mesocarp (fruit pulp) and seed while alkaloids and steroids were detected in the seed only. Furthermore, flavonoids and cardiac glycosides are detected only in the mesocarp. Tannins, cardenolides and anthraquinone were not detected in both the mesocarp and seed of D. microcarpum. There was depressed feed intake and daily weight gain of rats in groups $C(M 2: 1 R), D(S 1: 2 R)$ and $E(S 2: 1 R)$ and hence their growth when compared with the control (group A).

The results of this investigation suggest that fruit of D. microcarpum could have advert effect on theratsand may contain some anti-nutrients that might have interfered with its digestion and absorption, hence the observed retardation in the growth of rats fed with this fruit.
\end{abstract}

Keywords:Nutritional values, phytochemical constituents, Detarium microcarpum, fruits, rat growth.

\section{Introduction}

Through the ages, plants have been used by humans as sources of food, cosmetics and medicine. Plants have served as the basis of supplementing traditional medicine for thousands of years, in countries such as India, China (Cragg, 1999) and Nigeria. Fruit, bark and leaves of plants such as Sweet detar (D.microcarpum) are used not only for medicine, texture and flavour, but also for their nutritional values (Abulude et al., 2004).

D. microcarpum bears different local names among socio-cultural groups of different countries. For examples, socio-cultural groups like Yoruba, Igbo, Kanuri and Hausa in Nigeria named the plant as Ogbogbo, Ofo, Gatapo and Taure while Fulbe, Sonrai and Soninke in Mali called it Doli, Tambacounba and Fantu respectively (Kouyaté, 2005).

Sweet detar, D.microcarpum belongs to the family Fabaceae. It is very common locally in wooded savannahs; shrub savannahs and semi-cleared dry forest areas and is one of the most abundant species in fallows (Kido and Kim, 2012). There are two types of sweet detar trees. They are the tall (up to $40 \mathrm{~m}$ ) and small (5-10 $\mathrm{m})$ (Okorie et al., 2003) types. The tall type grows in the forests. These have reddish pods containing yellow pulp, which tastes somewhat bitter and therefore is not edible. The small type grows in savanna. These have brownish pods when matured and greenish pulp, which is eaten (Abdalbasit et al., 2009). D. microcarpum is hard, dark-brown wood which provides very good quality timber which is very durable under water and is used in carpentry and construction. It is also used as good quality fuel wood and charcoal. The leaves, stems, roots, barks, as well as the fruits have found tremendous usage in treatment of various ailments like tuberculosis, meningitis, itching and diarrhoea (Obun et al., 2010). Itis a leguminous tree from West Africa that bears pods containing sweet sour pulp which is popularly eaten by local people. The fruit is rich in vitamin $\mathrm{C}$ and the leaves and seeds are also used in cooking. The fruit may be eaten raw or cooked, but traditionally, the mesocarp is transformed into flour used in the preparation of cakes, bread, couscous, baby food and local beer. Seed kernels are added to egusi soup (generic name for seeds of some Cucurbitaceae species) or are cooked and eaten as a vegetable (Vautier et al.,2007).

It is therefore necessary that the fruit be investigated to study its phytochemical compositions that are responsible for its ethnobotanical purposes, and its nutritional benefits, as the flesh is eaten raw and cooked by many ethnic groups, especially in the northern part and middle belt of Nigeria. 


\section{Materials}

\section{Materials And Methods}

\section{Collection of sample}

Fruits of D.microcarpum were collected from Gbugudu village in Moro Local Government Area of Kwara State, Nigeria, and identified by Dr. A. A. Folunsho, a plant biologist in Obafemi Awolowo University, Ile Ife, Osun State.

\section{Experimental Animals}

Thirty five healthy mixed sexalbino rats of four weeks old were obtained from Success Street, flower garden, G.R.A.,Ilorin, Kwara State, Nigeria. The rats were individually housed in cages at 12 hours light cycle.

\section{Chemicals and Reagents}

All chemicals and reagents were of analytical grade and of high commerciallyavailable purity, obtained from British drug house; Poole, UK.

\section{Methods}

Separation of fruit into mesocarp and seed

The fruits of D. microcarpum, were collected and sun-dried consistently until they were properly dried. They were then lightly pounded (to avoid seed breakage) with a pestle and mortar to separate the seeds from the mesocarp.The mesocarp was then stored in a water proof container. Similarly, separated seeds were then milled and kept in a water proof container until needed.

\section{Experimental design}

The rats $(n=35)$ were divided into five groups $(n=7$ rats per group). Test diets were formulated by mixing mesocarp with rat mash in different ratios. Similarly, seed cake was mixed with rat mash in different ratios while the control diet was made up of rat mash onlyas shown below:

Group A: Rat mash only

Group B: Mesocarp 1:2 Rat mash

Group C: Mesocarp 2:1 Rat mash

Group D: Seed 1: 2 Rat mash

Group E: Seed 2:1 Rat mash.

The rats were allowed to acclimatize for one week prior to diet treatment. Water and feeds were provided ad libitum throughout the study period (4 weeks). Weekly weight gained in different groups was observed while total feeds consumed were also estimated.At the end of experimental period, individual rat was weighed and anaesthetized with chloroform. Liver, heart and kidney from both control and test animals were removed and weighed for comparison.

\section{Qualitative Phytochemical Screenings of Mesocarp and Seed}

Extracts were tested for the presence of active principles such as Anthraquinone, Triterpenes, Steroids, Cardiac Glycosides, Saponins, Alkaloids, Flavonoids, Tannins, phenolics and cardenolides (Sofowora, 1993).

\section{Proximate Analysis of Mesocarp and Seed}

The method of Adewale and Faremi, (2010) was used to determine the proximate analysis of D.microcarpum fruit as follow:

\section{Determination of Moisture Content}

Three grams $(3 \mathrm{~g})$ of the sample powder was weighed into empty crucible with initial weight $\left(\mathrm{W}_{0}\right)$. Weight of the sample with the crucible $\left(\mathrm{W}_{1}\right)$ was dried in an oven at $80^{\circ} \mathrm{C}$ until constant weight $\left(\mathrm{W}_{2}\right)$ was obtained. Percentage moisture content was calculated thus:

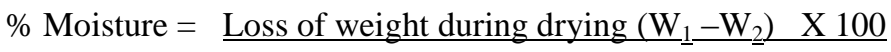

Weight of sample before drying $\left(\mathrm{W}_{1}-\mathrm{W}_{0}\right)$

\section{Determination of Crude Ash}

Two grams $(2 \mathrm{~g})$ of the powdered sample was accurately weighed into crucible of known weight. The sample was ashed/ burnt in a furnance at $550^{\circ} \mathrm{C}$ for 7-9 hours. The burnt sample was cooled in a desiccator and weighed. The percentage ash content was calculated thus:

$$
\% \text { Ash }=\underline{\text { (weight after ashing })-(\text { weight of empty dish }) \times 100}
$$

\section{Weight of sample}




\section{Determination of Crude Fat}

Ten grams $(10 \mathrm{~g})$ of the sample was weighed into a pre-weighed conical flask. $10 \mathrm{ml}$ of concentrated $\mathrm{HCl}, 3 \mathrm{ml}$ of distilled water and $2 \mathrm{ml}$ of ethanol were added into the flask. The mixture was shaken and put onto the water bath until it turns black. The black mixture was poured into a separating funnel and $25 \mathrm{ml}$ of petroleum spirit with diethyl ether was added. The non-aqueous fraction was collected and evaporated to dryness on a water bath. The conical flask with the sample was re-weighed and percentage crude fat was calculated thus:

$\%$ Crude Fat $=\underline{(\text { weight of flask }+ \text { fat })-(\text { weight of empty flask })} \times 100$

Weight of sample

\section{Determination of Crude Fibre}

Two grams ( $2 \mathrm{~g}$ ) of sample was weighed into a conical flask $\left(\mathrm{W}_{0}\right)$. Twenty (20) $\mathrm{ml}$ of $10 \% \mathrm{H}_{2} \mathrm{SO}_{4}$ was added and boiled gently for 30 minutes. The mixture was filtered through a poplin cloth stretched over a Buchner funnel, rinsed with hot distilled water and the residue was scraped back into the flask with spatula. Then $20 \mathrm{ml}$ of $10 \% \mathrm{NaOH}$ was added and boiled gently for 30 minutes and filtered through poplin cloth. The residue was washed thoroughly with hot distilled water and rinsed once with $10 \% \mathrm{HCl}$ and twice with ethanol. It was then rinsed thrice with petroleum ether and allowed to drain dry. The residue was scraped into a crucible and oven dried for 24 hours at $105^{\circ} \mathrm{C}$. It was cooled in the desiccator and weighed as $\left(\mathrm{W}_{1}\right)$. It was ashed at $550^{\circ} \mathrm{C}$ for 90 minutes in furnace and cooled in the desiccator and the final weight taken as $\mathrm{W}_{2}$. The percentage of crude fibre was calculated thus:

$$
\% \text { Crude fibre }=\underline{\mathrm{W}}_{1} \underline{-}-\mathrm{W}_{2}=100
$$

$\mathrm{W}_{0}=$ Weight of sample,

$\mathrm{W}_{1}=$ Dry weight of the residue,

$\mathrm{W}_{2}=$ Weight of ash.

\section{Determination of Crude Protein}

Ten $\mathrm{ml}(10 \mathrm{ml})$ of the sample was measured into a conical flask and 3 drops of $1 \%$ phenolphthalein was added. The mixture was titrated to the end point with $0.1 \mathrm{M} \mathrm{NaOH}$. Two $\mathrm{ml}(2 \mathrm{ml})$ of $40 \%$ formaldehyde was added to the already titrated acidity (from acidity of the sample) before titrating again with $0.1 \mathrm{M} \mathrm{NaOH}$ and the titre value was gotten as T.V. The steps were repeated with $10 \mathrm{ml}$ of distilled water and $1 \mathrm{ml}$ of phenolphthalein before titrating for blank. Percentage crude protein is calculated thus:

$1.95=$ Multiplication factor for protein

$$
\% \text { Crude Protein }=(\text { T.V }- \text { Blank }) \times 1.95
$$

\section{Determination of Total Carbohydrate}

Tengrams $(10 \mathrm{~g})$ of the sample was diluted to $100 \mathrm{ml}$ with distilled water; $1 \mathrm{ml}$ of the distilled filterate was added into a test tube in duplicate. Duplicate blanks were prepared each with $1 \mathrm{ml}$ of distilled water in lieu of the distilled filterate. Standard carbohydrate solution using $1 \mathrm{ml}$ of dilute D-glucose $(10-100 \mu \mathrm{g} / \mathrm{ml})$ was prepared, $5 \mathrm{ml}$ portions of freshly prepared anthrone reagent was added to the content of each tube and mixed properly. The mixture was incubated in a boiling water bath for $12 \mathrm{~min}$ and cooled quickly to room temperature. The absorbance was read at $620 \mathrm{~nm}$ against the reagent blank using spectrophotometer and the total available carbohydrate of each sample was obtained directly from the standard carbohydrate curve (Adewale and Faremi, 2010).

\section{Statistical Analysis}

Results were expressed as Mean $\pm \mathrm{SD}$. The data were analysed by one way analysis of variance (ANOVA) and Duncan Multiple Range Test to separate treatment means. The $\mathrm{p}$ values of $<0.05$ were considered statistically significant.

\section{Results}

Saponins, phenolics and terpenoids were detected in both the mesocarp and seed. Alkaloids and steroids were detected in the seed only while flavonoids and cardiac glycosides were detected only in the mesocarp. Tannins, cardenolides and anthraquinone were not detected in both the seed and mesocarp of $D$. microcarpum (table 1).

The moisture and total carbohydrate contents of mesocarp were higher than those of the seed while crude fat, crude fibre, crude ash and crude protein in the seed were significantly higher than those of the mesocarp (Table 2). 
There was a significant increase in the feed consumed by groups A and B throughout the experimental period. Similarly, there was an increase in the amount of feed consumed by groups $\mathrm{C}$ and $\mathrm{E}$ rats in the $2^{\text {nd }}$ week, but thereafter, a decrease in consumption in the $3^{\text {rd }}$ and $4^{\text {th }}$ weeks was observed. However, feed consumption in group D rats did not follow any pattern (Table 3 ).

There was no significant difference in the growth between the rats in all the groups at the end of the $1^{\text {st }}$ week of the treatment. However, the weight gained by the rats in groups A and B are significantly higher than those in groups C, D and E at the end of the $2^{\text {nd }}$ and $3^{\text {rd }}$ weeks of treatment. At the end of the $4^{\text {th }}$ week of treatment, the weight gained by the rats in group A (control) was significantly higher than those of all other groups. At the end of the experiment, rats in groups C, D and E had significant reduction in weight compared to their initial weights (Table 4). The feed intake, final weight and weight gain of the rats were increased in groups A and B but decreased as the quantity of D. microcarpum fruit supplement was increasing in the diets.

The heart: body weight of group A rats were significantly reduced compared with groups B and C whereas, it is not significantly different with those of groups D and E. However, the kidney: body weight of group A rats was significantly reduced compared with other groups (B-E) that was fed with D. microcarpum fruit supplement. Furthermore, the liver: body weight of group A rats were significantly different with those of groups $\mathrm{C}-\mathrm{E}$ but there was no significant difference with group B (Table 5).

Table 1: Qualitative phytochemical screening of Detarium Microcarpum fruit

\begin{tabular}{|c|c|c|}
\hline Phytochemicals & Mesocarp & Seed \\
\hline Saponins & + & + \\
\hline Flavonoids & + & - \\
\hline Phenolics & + & + \\
\hline Alkaloids & - & + \\
\hline Steroids & - & + \\
\hline Tannins & - & - \\
\hline Terpenoid & + & + \\
\hline Cardiac Glycosides & + & - \\
\hline Cardenolides & - & - \\
\hline Anthraquinone & - & - \\
\hline
\end{tabular}

Results are mean \pm SD of duplicate determinations.

KEY: + indicates phytochemicals detected and-indicates phytochemicals not detected.

Table 2: Proximate analysis of Detarium microcarpum fruit

\begin{tabular}{lcc}
\hline & \multicolumn{2}{c}{ Percentage (\%) } \\
\cline { 2 - 3 } Nutrients & Mesocarp & Seed \\
\hline Moisture Content & $15.0 \pm 0.01$ & $5.0 \pm 0.01$ \\
Crude Fat & $10.5 \pm 0.01$ & $15.5 \pm 0.02$ \\
Crude Ash & $3.3 \pm 0.01$ & $3.5 \pm 0.02$ \\
Crude Fibre & $10.2 \pm 0.02$ & $11.2 \pm 0.01$ \\
Crude Protein & $6.0 \pm 0.03$ & $13.5 \pm 0.02$ \\
Total Carbohydrate & $54.9 \pm 0.01$ & $50.5 \pm 0.03$ \\
\hline
\end{tabular}

Results are mean \pm SD of duplicate determinations 
Table 3: Feed intake of rats $(\mathrm{g})$

\begin{tabular}{cccccc}
\hline Week & $\begin{array}{c}\mathbf{A} \\
\mathbf{R} \text { only }\end{array}$ & $\begin{array}{c}\mathbf{B} \\
\mathbf{M 1 : 2 R}\end{array}$ & $\begin{array}{c}\text { Feed Intake }(\mathbf{g}) \\
\mathbf{C} 2: \mathbf{1 R}\end{array}$ & $\begin{array}{c}\mathbf{D} \\
\mathbf{S 1 : 2 R}\end{array}$ & $\begin{array}{c}\mathbf{E} \\
\mathbf{S 2 : 1 R}\end{array}$ \\
\hline 1 & 210.0 & 210.0 & 202.3 & 175.2 & 27.9 \\
2 & 600.0 & 356.5 & 267.2 & 91.9 & 70.0 \\
3 & 720.0 & 400.0 & 257.0 & 228.0 & 26.5 \\
4 & 830.0 & 440.0 & 245.0 & 210 & 23.0 \\
\hline \multicolumn{5}{r}{ Results are mean \pm SD of seven determinations }
\end{tabular}

Table 4: Growth effect of Detarium microcarpum fruit on Albino rats (g)

\begin{tabular}{|c|c|c|c|c|c|}
\hline \multirow[t]{2}{*}{ Weeks } & \multicolumn{5}{|c|}{ Groups } \\
\hline & $\begin{array}{c}\text { A } \\
\text { R only }\end{array}$ & $\begin{array}{c}\text { B } \\
M 1: 2 R\end{array}$ & $\underset{M 2: 1 R}{C}$ & $\begin{array}{c}\text { D } \\
\text { S1:2R }\end{array}$ & $\begin{array}{c}E \\
S 2: 1 R\end{array}$ \\
\hline 0 & & & & & \\
\hline & $116.7 \pm 14.24^{\mathrm{a}}$ & $99.5 \pm 13.26^{\mathrm{a}}$ & $111.0 \pm 9.48^{\mathrm{a}}$ & $118.9 \pm 5.79^{a}$ & $118.9 \pm 10.79^{a}$ \\
\hline & $118.5 \pm 2.86^{\mathrm{a}}$ & $101.0 \pm 1.48^{\mathrm{a}}$ & $111.4 \pm 0.33^{\mathrm{a}}$ & $115 \pm 3.16^{\mathrm{a}}$ & $115.3 \pm 4.99^{\mathrm{a}}$ \\
\hline 2 & $141.5 \pm 3.00^{\mathrm{a}}$ & $105.2 \pm 3.48^{\mathrm{a}}$ & $97.9 \pm 3.21^{\mathrm{b}}$ & $96.8 \pm 1.47^{\mathrm{b}}$ & $90.4 \pm 3.67^{b}$ \\
\hline & $161.4 \pm 4.77^{\mathrm{a}}$ & $112.0 \pm 3.21^{\mathrm{a}}$ & $88.1 \pm 1.23^{b}$ & $87.5 \pm 1.67^{b}$ & $99.2 \pm 3.56^{\mathrm{b}}$ \\
\hline & $173.9 \pm 6.43^{a}$ & $126.1 \pm 6.57^{\mathrm{d}}$ & $96.3 \pm 8.20^{c}$ & $78.9 \pm 5.52^{b}$ & $90.8 \pm 12.29^{c}$ \\
\hline $\begin{array}{l}\text { Weight } \\
\text { gained }\end{array}$ & 57.2 & 26.6 & -14.7 & -40.0 & -28.1 \\
\hline
\end{tabular}

Results are mean \pm SD of seven determinations

Values with different letters across the same row are significantly different from each other.

$$
\begin{gathered}
\text { R only = Rat mash only } \\
\text { M1:2R = Mesocarp 1:2 Rat mash } \\
\text { M2:1R = Mesocarp 2:1 Rat mash } \\
\text { S1:2R = Seed 1:2 Rat mash } \\
\text { S2:1R = Seed } 2: 1 \text { Rat mash }
\end{gathered}
$$

\begin{tabular}{|c|c|c|c|}
\hline \multirow{2}{*}{ Groups } & \multicolumn{3}{|c|}{ Organ: Body Weight } \\
\hline & Heart & Kidney & Liver \\
\hline A (R only) & $0.003 \pm 0.0003^{\mathrm{a}}$ & $0.007 \pm 0.0010^{\mathrm{a}}$ & $0.040 \pm 0.0030^{\mathrm{a}}$ \\
\hline B (M1:2R) & $0.004 \pm 0.0005^{\mathrm{b}}$ & $0.008 \pm 0.0010^{\mathrm{b}}$ & $0.041 \pm 0.0030^{\mathrm{a}}$ \\
\hline C (M2:1R) & $0.004 \pm 0.0007^{b}$ & $0.008 \pm 0.0018^{b}$ & $0.050 \pm 0.0040^{b}$ \\
\hline D (S1:2R) & $0.003 \pm 0.0004^{\mathrm{a}}$ & $0.008 \pm 0.0018^{b}$ & $0.038 \pm 0.0071^{\mathrm{c}}$ \\
\hline E (S2:1R) & $0.003 \pm 0.0004^{\mathrm{a}}$ & $0.008 \pm 0.0018^{b}$ & $0.036 \pm 0.0064^{\mathrm{d}}$ \\
\hline
\end{tabular}

Table 5: Organ: body weight of rats fed with $D$. microcarpum fruit supplement

Results are mean \pm SD of seven determinations

\section{Discussion}

The phytochemical substances and nutritional values of mesocarp and seedin D. microcarpum fruit are shown in tables 1 and 2 respectively. The variation in the phytochemicals and nutrients present in the mesocarp and seed is an indication that different parts of the same plant could have different types and varying concentrations of phytochemicals and nutrients. These phytochemicals present may be responsible for the medicinal/ethnobotanical uses of the plant. The mesocarp of D. microcarpum hashigh moisture content compared to the seed. This is an indication that the seed can be storedfor a longer time compared to the mesocarp without deterioration. This further implies that the seeds may still be viable even after the mesocarp has decayed. The higher fibre content of the seedcompared to that of mesocar pcould be due to the relative thick seed coats. The percentage crude fat obtained for the seed was higher $(15.5 \%)$ compared with 
themesocarp(10.5\%). This may be due to the fact that seeds of plants do contain higher percentage of fat than any other parts of the plants.

The eating pattern and growth performance of the rats fed with mesocarp andseed of D.microcarpum is presented in Tables 3 and 4. The observed decreased in feed intake andfinal weight of the rats in groups C, D and $\mathrm{E}$ as the quantity of $D$. microcarpum fruit supplement was increasing in the diets could be attributed to the relatively high crude fibre and inherent anti-nutritional factors that might be present in the fruit. High dietary fibre level has been shown to depress feed and consequently nutrient intake in animals (Kass et al., 1980). In addition, the observed retardation in the growth of rats fed with D. microcarpum may be due to anti-nutrients that might be present in the feed formula. Anti-nutrients are natural or synthetic compounds that interfere with the absorption of nutrients (Oxford, 2006). Nutrition studies focus on those anti-nutrients commonly found in food sources and beverages. Examples include saponins, tannins, flavonoids, phytic acid and oxalic acid. For instance, flavonoids are a group of polyphenolic compounds that include tannins, which chelate metals such as iron and zinc and reduce the absorption of these nutrients. They also inhibit digestive enzymes and may also precipitate proteins (Beecher, 2003). Some proteins can also be anti-nutrients, such as the trypsin inhibitors and lectins found in legumes (Gilani et al., 2005). These enzyme inhibitors interfere with digestion. There may be presence of these types of protein anti-nutrients/inhibitors in D. microcarpum fruit, which prevent digestion and subsequent absorption in rats fed with it.It has also been reported that saponin impairs performance through its irritating effect on the linings of the mouth and guts and through its bitter taste. Saponins in plants may serve as anti-feedants (Weintraub, 1993). Furthermore, most alkaloids have bitter taste and some are poisonous when ingested (Carey, 1987). This could be attributed to the low consumption of feed formula/diet, which eventually led to decreased in the quantity of feed intake and hence, subsequent retardation in growth and loss in weights.

The increase in the size of liver of rats fed on seed diets may be due to the effects of saponin toxicity in the feed causing inflammation and friable liver (Roscchack et al., 1986). Although both mesocarp and seed formula contain saponins, the concentrations may not be the same, hence, its manifestation in rats fed with seed feed formula.

Excessive intake of required nutrients can also result in them having an anti-nutrient action. Pearson (2007) has reported that excessive intake of fibre can reduce the transit time through the intestines to such a degree that other nutrients cannot be absorbed. Therefore, increase in the ratios of mesocarp (M2:1R) and seed (S2:1R) in feed formula may have contributed to the cumulative effects of these anti-nutrients.

However, animals that were fed with mesocarp supplementary in group 2 recorded little increase in growth (although cannot be compared with the control formula, which recorded significant increase) but none of the groups fed with seed supplementary formula recorded any increase in their growth, instead there was a reduction. This observation may be that seeds of D. microcarpum fruit contain higher amount of anti-nutrients compared with its mesocarp.

\section{Conclusion}

This investigation revealed that D. micocarpum fruits contain some phytochemical substances, which may be responsible for its medicinal uses for the treatment of certain diseases/ailments. The fruits are a rich source of nutrients but may contain anti-nutritional factors, although the mesocarp supplement diet could be tolerated up to $35 \%(\mathrm{M} 1: 2 \mathrm{R})$ inclusion levels compared to $35 \%$ seed supplement diet (S1:2R), which led to reduction in growth and weight of rats.

However, it is suggested that the fruits of D. micocarpums hould be cooked for several minutes to neutralize the inherent anti-nutritional substances in order to make its nutrients available for the consumers. Cooking increases nutritive quality of plant foods through the reduction of certain anti-nutrients such as phytic acid, polyphenols, and oxalic acid (Hotz and Gibson, 2007).

\section{References}

[1]. Abdalbasit, Adam Mariod, Mohamed Elwathig S. Mirghani, Ahmad Bustamam Abdul and Siddig Ibrahim Abdelwahab (2009):Detarium microcarpum Guill and Perr fruit proximate chemical analysis and sensory characteristics of concentrated juice and jam. African Journal of Biotechnology 8 NO.17: 4217-4221.

[2]. Abulude, F.O., Onibon, V.O. and Oluwatoba, F. (2004): Nutritional and nutritional compositions of some tree barks. Nigerian Journal of Basic and Applied Sciences, 13: 43-49.

[3]. Adewale O. andFaremi A.Y. (2010):Introduction to Experimental Biochemistry.Chapter 4: 44-53; Chapter 5: 54-65.

[4]. Beecher GR (2003): Overview of dietary flavonoids: nomenclature, occurrence and intake. J. Nutr.133 (10): 3248S-54S

[5]. Carey, F. A. (1987): Organic Chemistry. $6^{\text {th }}$ edition. New York. McGraw-Hill, 1954.

[6]. Cragg, G.M. (1999): Testimony on Medicinal plant educational and health Librans. Pp. 465.

[7]. Gilani GS, Cockell KA, Sepehr E (2005): Effects of antinutritional factors on protein digestibility and amino acid availability in foods. J AOAC Int88 (3): 967-87.

[8]. Hotz C, Gibson RS (April 2007): Traditional food-processing and preparation practices to enhance the bioavailability of micronutrients in plant-based diets. J. Nutr.137 (4): 1097-100.

[9]. Kass, M. L., Van Soest, P. J., Pond, W. G,, Lewis, B. and McDowell, R. E. (1980): Utilization of dietary fibre from alfalfa by growing swine. 1. Apparent digestibility of diet components in specific segments of the gastrointestinal tract. Journal of Animal Science, 50: $175-191$

[10]. Kido F.W. and Kim N.I. (2012): Sweet detar: Food, Fragrance, Fodder, and More,” Nourishing the Planet. 
[11]. Kouyaté AM. (2005): Aspects ethnobotaniquesetétude de la variabilitémorphologique, biochimiqueetphénologique de Detarium microcarpum Guill. \&Perr.au Mali. Thèse de Doctorat.FacultédesSciencesBiologiquesAppliquées,Université de Gand, Belgique.207 pp.

[12]. Ky-Dembele C, Tigabu M, Bayala J, Ouédraogo JS and Odén PC. 2008. Comparison between clonal and sexual plantlets of DetariummicrocarpumGuill. \&Perr., a savanna tree species in Burkina Faso. African Journal of Ecology 46(4):602-611.

[13]. Obun, C.O. Yahaya S.M, Kibon, A.A. Olafadehan, O.A. and Alison, S.D. (2010): Evaluation of Detarium microcarpum pulp meal as food ingredient in rabbits diets. EJEAFCHE, 9 (2) $308-314$.

[14]. Okorie, S.U. and E.C. Amechi, (2003): Effects of roasting and soaking on the proximate composition and functional properties of selected tropical legumes. Global Journal of Pure and Applied Sciences, 9(2): 177-182.

[15]. Oxford Dictionary of Biochemistry and Molecular Biology.Oxford University Press, 2006.

[16]. Pearson Benjamin Cummings (2007):Nutrition: A Functional Approach, Canadian Edition.

[17]. Rosochacki, S. R., Grosley, B. and Keller, J. S. (1986): Effect of feed intake on some lysozomalproteolytic activities in pectoral and leg muscles of growing chickens. Achive for Gefugelkinde, 50:7-12.

[18]. Sofowora, A.E. (1993):Medicinal plants and Traditional medicine in Africa.Spectrum Books Ltd., Ibadan. 288 Pp.

[19]. Vautier H, Sanon M and Sacande M. (2007):Detarium microcarpum Guill. \&Perr.Seed Leaflet 122.Forest \& Landscape Denmark, Hørsholm, Denmark. Available at: http://en.sl.life.ku.dk/upload/122net.pdf. Accessed 18 February 2014.

[20]. Weintraub, B. (1993): Masai Diet Wards of Heart Disease, Geographica. 112-4. 